\title{
Federal Rule of Civil Procedure 60(b): Standards for Relief from Judgments Due to Changes in Law
}

In order to protect the finality of judgments, federal courts have often asserted that relief from a final judgment may not be granted due to a subsequent change in the judge-made law on which a court relied in reaching the judgment. ${ }^{1}$ Such assertions are belied by the facts: relief due to a subsequent change in law was available in the federal courts under the writ system that existed prior to the enactment of the Federal Rules of Civil Procedure, ${ }^{2}$

' See, e.g., Lubben v. Selective Serv., 453 F.2d 645, 650 (1st Cir. 1972); Title v. United States, 263 F.2d 28, 31 (9th Cir. 1959); Collins v. City of Wichita, 254 F.2d 837, 839 (10th Cir. 1958); Berryhill v. United States, 199 F.2d 217, 219 (6th Cir. 1952); Loucke v. United States, 21 F.R.D. 305, 308 (S.D.N.Y. 1957). Professor Moore has also made this assertion. See 7 J. Moore, Federal Practice I 60.26[3], at 325 (2d ed. 1974) [hereinafter cited as Moore].

This comment deals only with a change in judge-made law. It is settled that a change in statutory law will not serve as the basis of relief from a final judgment. See Ross v. Oregon, 227 U.S. 150, 160-63 (1913).

If the judgment has not become final, there is no question that relief may be obtained due to a change of judge-made law. In United States v. Schooner Peggy, 5 U.S. (1 Cranch) 103 (1801), the Supreme Court laid the foundation for this principle by granting relief in a judgment still sub judice. In Vandenbark v. Owens-Illinois Glass Co., 311 U.S. 538 (1941), the Court extended this rule to diversity actions in stating that "[u]ntil such time as a case is no longer sub judice, the duty rests upon Federal courts to apply state law under the Rules of Decision Statute in accordance with the then controlling decision of the highest state court." 311 U.S. at 543. See also Huddleston v. Dwyer, 322 U.S. 232 (1944).

2 Prior to the amendment of the Federal Rules in 1948 to include subsections 60(b)(4)(6), relief from judgments was available under the writ system. In the event of a change of law, relief was sought under the writs of audita querela, coram nobis, or coram vobis and, for judgments in equity, through a bill of review. Broadly stated, the writ of audita querela applied to matters arising after the judgment, such as the discovery of new facts, discharge of the judgment, or a change of law. Coram nobis and coram vobis applied to clerical errors or the error or omission of facts in the original judgment. The bill of review incorporated both of these writs for judgments in equity. See 7 Moore, supra note 1, ff 60.12-.15, at 33-72; Moore \& Rogers, Federal Relief from Civil Judgments, 55 YALE L.J. 623, 659-82 (1946) [hereinafter cited as YALE ARTICLE].

The lack of clarity of the scope of relief available under the writs must be emphasized. See Klapprott v. United States, 335 U.S. 601, 614 (1949). For example, although the primary scope of the writ of audita querela was to provide relief based on matters occurring subsequent to the judgment, this rule was frequently ignored. YaLE ARTicle, supra, at 660. But see Luparelli v. United States Fire Ins. Co., 117 N.J.L. 342, 188 A. 451 (1936). In abolishing the writs, the Federal Rules incorporated the relief provided by them. Justice Black noted in Klapprott v. United States that

[i]t is contended that the "other reasons" clause of Rule 60(b)(6) should be interpreted so as to deny relief except under circumstances sufficient to have authorized relief under the common law writs of coram nobis and audita querela, and that the facts shown here 


\section{and cases decided under rule $60(\mathrm{~b})$ of the Federal Rules currently} provide such relief. ${ }^{3}$ There are conflicting views on the standard that should govern the granting of relief due to a change in law. The primary source of the confusion has been the decision to grant or deny relief on the basis of the broad "extraordinary circumstances" standard of rule $60(\mathrm{~b})(6)$. The courts have generally proceeded under clause (6) and, without adequate guidance, have been forced to resolve petitions for relief based on their own notions of justice. This unguided discretion raises the possibility that inconsistent results will be reached by different courts in applying the same legal standard to substantially similar facts. In light of this situation, this comment argues that relief should be available under clause (5) rather than clause (6) of rule 60(b). An application of the literal language of clause (5) would provide more concrete guidelines for

would not have justified relief under these common law proceedings. One thing wrong with this contention is that few courts ever have agreed as to what circumstances would justify relief under these old remedies. To accept this contention would therefore introduce needless confusion in the administration of rule $60(\mathrm{~b})$ and would also circumscribe it within needless and uncertain boundaries. Furthermore rule $60(\mathrm{~b})$ strongly indicates on its face that courts no longer are to be hemmed in by the uncertain boundaries of these and other common law remedial tools.

335 U.S. at 614; see Bankers Mort. Co. v. United States, 423 F.2d 73 (5th Cir. 1970). But see Lapin v. Shulton, Inc., 333 F.2d 169 (9th Cir. 1964). Although examination of the writs is useful in ascertaining the nature and scope of relief available in past cases, the writs do not determine the scope of relief presently obtainable.

${ }^{3}$ See, e.g., Pierce v. Cook \& Co., 518 F.2d 720 (10th Cir. 1975), cert. denied, 96 S. Ct. 866 (1976); Tsakonites v. Transpacific Carriers Corp., 322 F. Supp. 722 (S.D.N.Y. 1970).

Rule 60 currently provides that:

(b) Mistakes; Inadvertence, Excusable Neglect; Newly Discovered Evidence; Fraud, etc. On motion and upon such terms as are just, the court may relieve a party or his legal representative from a final judgment, order, or proceeding for the following reasons: (1) mistake, inadvertence, surprise, or excusable neglect; (2) newly discovered evidence which by due diligence could not have been discovered in time to move for a new trial under Rule 59(b); (3) fraud (whether heretofore denominated intrinsic or extrinsic), misrepresentation, or other misconduct of an adverse party; (4) the judgment is void; (5) the judgment has been satisfied, released or discharged, or a prior judgment upon which it is based has been reversed or otherwise vacated, or it is no longer equitable that the judgment should have prospective application; or (6) any other reason justifying relief from the operation of the judgment. The motion shall be made within a reasonable time, and for reasons (1), (2), and (3) not more than one year after the judgment, order, or proceeding was entered or taken. A motion under this subdivision (b) does not affect the finality of a judgment or suspend its operation. This rule does not limit the power of a court to entertain an independent action to relieve a party from a judgment, order, or proceeding, or to grant relief to a defendant not actually personally notified as provided in Title 28 , U.S.C. $\S 1655$, or to set aside a judgment for fraud upon the court. Writs of coram nobis, coram vobis, audita querela, and bills of review and bills in the nature of a bill of review, are abolished, and the procedure for obtaining any relief from a judgment shall be by motion as prescribed in these rules or by an independent action. 
relief while allowing the achievement of equitable results without the high degree of uncertainty which clause (6) has generated.

Part I of the comment identifies the factors that should govern in the choice of an appropriate standard for granting or denying relief due to a change in law. In particular, the conflicting goals of the finality of judgments and the equitable disposition of individual cases are examined. Part II of the comment discusses and criticizes the manner in which clause (5) and clause (6) have been applied by the courts. Part III proposes the use of an expanded definition of the standard embodied in clause (5) to govern relief due to a change in law and explores the implications of this suggestion.

\section{The Factors Involved in Formulating a Standard}

That litigation should finally come to an end is a well recognized principle. On the other hand, a totally inflexible rule of finality might cause injustice in particular cases. An acceptable standard for granting relief from a final judgment must be the product of a careful compromise between these principles. This compromise cannot be reached without a brief examination of the constituent elements of the concerns relating to finality and equitable results.

The principle of finality is expressed primarily through the related doctrines of res judicata and stare decisis. Under the former doctrine, a final judgment on the merits is an absolute bar to a subsequent action between the same parties, or those in privity with the original parties, based on the same claim or cause of action. In addition, as to matters which were necessarily litigated and determined pursuant to a final judgment in one claim, the judgment constitutes an estoppel as to those matters in a later action even though the second action is based on a different claim. ${ }^{4}$ Stare decisis is composed of two competing elements. The first element requires a court to abide by the rules of law it has developed or which have been developed by other courts to which it owes obedience. The doctrine also requires the self-correction of error under appropriate circumstances. ${ }^{5}$ Because of the competition set up by these two elements of stare decisis, this doctrine commands a lesser degree of finality than does the doctrine of res judicata. ${ }^{6}$

The finality principle accomplishes several objectives important to the judicial system. The achievement of a final resolution

\footnotetext{
- 6A MOORE, supra note 1,1 60.02, at 4019 .

Id. at 4022.

Id. at 4022-23.
} 
of disputes furthers the goal of social stability, for "the aid of judicial tribunals would not be invoked for the vindication of rights . . . if . . . conclusiveness did not attend the judgments of such tribunals." Another goal served by the principle of finality, through the doctrine of stare decisis, is the goal of certainty in the legal standards to be applied in similar fact situations. This certainty furthers efficient judicial administration by lessening the degree to which the courts must rely on their own discretion and provides individuals with a basis on which to gauge their conduct. ${ }^{8}$ As expressed through the doctrine of res judicata, the principle of finality serves the important purpose of allowing litigants and third parties to rely and act upon the basis of a final judgment, thus also serving the goals of consistency and certainty. ${ }^{9}$

A determination as to when the principle of finality of judgments should be relaxed should proceed on the assumption that relief from judgment should be granted in a manner that conflicts least with the goals served by finality. Broadly stated, justice requires that individuals receive similar treatment from the courts. The heart of this requirement is that similar controversies involving similar claims under equivalent situations should reach the same results. When the law changes, litigants may receive disparate treatment; to equalize this treatment, relief from a judgment may be necessary. Relief is equitable when its goal is the achievement of consistent results. ${ }^{10}$ Although relief from final judgment is at times appropriate to achieve a consistent and equitable result, there must be limitations on the availability of such relief.

The limitations on relief are based on equitable considerations. If a third party has reasonably relied and acted upon a final judgment, and if reopening the judgment would injure or prejudice the third party, then it would seem unjust to reopen the judgment. The same considerations are not necessarily applicable when the reliance placed upon the final judgment is by one of the original parties to the suit. By itself, such reliance would not seem sufficient to prevent relief from judgments since the original parties may always claim reliance in an effort to avoid a reopening which may work to

7 Southern Pac. R.R. v. United States, 168 U.S. 1, 49 (1897) (Harlan, J.).

* Pierce v. Cook \& Co., 518 F.2d 720, 723 (10th Cir. 1975), cert. denied, 96 S. Ct. 866 (1976).

- United States v. Ohio Power Co., 353 U.S. 98, 110 (1957) (Harlan, J., dissenting). See generally 6A MooRE, supra note 1 , \60.02, at 4019-23.

to Gondeck v. Pan American World Airways, 382 U.S. 25 (1965); United States v. Ohio Power Co., 353 U.S. 98 (1957). Consistency is also an aspect of the finality of judgments. 
their personal detriment. When combined with other factors, however, reliance by one of the original parties may be sufficient to prevent reopening of the judgment. One such factor is the length of time that has passed since the judgment became final. The more time that has passed since the judgment became final, the more likely it is that the relying party will be prejudiced. This concept applies to reliance by third parties as well. Therefore, unless the party wishing to reopen the judgment moves to do so within a reasonable time after the judgment, relief should not be granted. The reasonableness of time should be interpreted in light of the potentiality for harm to parties who have relied on the finality of the judgment.

Relief should not be granted to a party who has failed to do everything reasonably within his power to achieve a favorable result before the judgment becomes final. If a party could have avoided conflicts with the principle of finality by doing everything within his power to achieve a favorable result before the judgment became final, but decided not to use the opportunity or neglected to do so, there are no compelling reasons to relieve him from the consequences of his own choice or negligence. Without this requirement, a rule granting relief from final judgment would likely degenerate into a mere substitute for appeal and completely subvert the principle of finality.

Consistent with the goals of certainty, efficient judicial administration, consistency of results, and social stability, an additional general limitation on a rule granting relief from final judgments may be derived. The standard itself must be clear in wording and meaning; in addition, there should be only one standard to cover a generic set of fact situations such as a change in law. A multiplicity of standards would lead inevitably to inconsistent results. To allow the courts to rely on a more general rule when a more specific and pertinent standard is available raises the danger of inconsistent results and promotes an inefficient judicial procedure. Rule 60(b) was adopted to provide a more definite standard for the granting of relief from final judgments; the problem is that the application of the rule has not resulted in narrowing the boundaries of relief sufficiently to establish an acceptable compromise between the goals of finality and equity.

\section{The Current Judicial Treatment of Rule 60(b)}

Before the Federal Rules of Civil Procedure were amended in 1948 , relief from judgment due to a change in law was available only 
through the writ system." Under current law, relief is available only under the provisions of rule 60(b)..$^{12}$ Furthermore, since the provisions of rule $60(\mathrm{~b})$ are mutually exclusive, only one clause may apply. ${ }^{13}$ The mutual exclusivity principle makes vitally important a procedural difference between the first three clauses and the last three clauses of the rule. Clauses (1) through (3) limit relief to within one year of the entry of judgment while clauses (4) through (6) allow relief within a "reasonable time" after the judgment is entered. ${ }^{14}$

"See note 2 supra. As adopted in 1938, the Federal Rules contained a savings clause which preserved relief under the writs. The original rule 60 provided relief from a judgment only in the event of mistake, inadvertence, surprise, or excusable neglect; such relief was

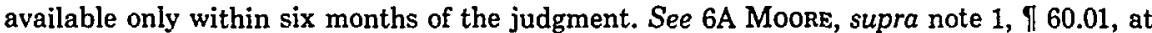
4007-16. In cases arising between 1938 and 1948, the courts held that both audita querela and a bill of review could provide relief from a final judgment in the event of a subsequent change of law. In International Ry. Co. v. Davidson, 65 F. Supp. 58 (W.D.N.Y. 1945), the court granted a bill of review in order to modify an injunction on the basis of Supreme Court dicta. In Oliver v. City of Shattuck, 157 F.2d 150 (10th Cir. 1946), plaintiff was a party to one of two similar cases; plaintiff did not appeal an adverse judgment. Implying that audita querela was applicable, the court granted relief from the final judgment when the tandem case was reversed; the exact basis of relief was not made clear. But see Phelan v. Bradbury Bldg. Corp. 7 F.R.D. 429 (S.D.N.Y. 1947), in which the plaintiff was denied relief from a settlement even though subsequent decisions entitled the plaintiff to greater relief.

12 According to rule 60(b), a court may still entertain an independent action in equity to relieve a party from a final judgment; such actions are, however, rare. $11 \mathrm{C}$. WRIGHT \& A. Miller, Federal Practice and Procedure 239 (1973) [hereinafter cited as Wright \& MiLLER].

is Klapprott v. United States, 335 U.S. 601, 614-15 (1949). See also United States v. Karahalias, 205 F.2d 331 (2d Cir. 1953). Although this clear rule of mutual exclusivity is important in determining whether relief is limited by the one year provision of rules 60(b)(1). (3), the courts have not emphasized this distinction. In fact, courts at times simply grant relief on the basis of rule 60(b) without specifying the specific clause on which they rely. See, e.g., Tarkington v. United States Lines Co., 222 F.2d 358 (2d Cir. 1955).

"The definition of "reasonable time" is uncertain. The cases, which grant relief after several years have elapsed but deny relief after several months, do not present a consistent definition. See, e.g., Klapprott v. United States, 335 U.S. 601 (1949) (four years reasonable); FDIC v. Alker, 234 F.2d 113 (3d Cir. 1956) (ten years reasonable); Tsakonites v. Transpacific Carriers Corp., 322 F. Supp. 722 (S.D.N.Y. 1970) (immediately after a change in the law-but five years after rendition of the final judgment-was reasonable); Pierre v. Bernuth, Lembcke Co., 20 F.R.D. 116 (S.D.N.Y. 1956) (three years, while plaintiff was in a mental institution, reasonable); In re Cremidas' Estate, 14 F.R.D. 15 (D. Alas. 1953) (three years reasonable). But see Delzona Corp. v. Sacks, 265 F.2d 157 (3d Cir. 1959) (one and a half years unreasonable); Morgan v. Southern Farm Bur. Cas. Ins. Corp., 42 F.R.D. 25 (W.D. La. 1967) (twentythree months per se unreasonable).

The only unifying principles that can be drawn from the cases are that the motion for relief must be made as soon as the disability-either physical or through a change of law-has been removed, and that the prejudice to intervening rights will, in effect, make the length of time unreasonable. In re Cremidas' Estate, 14 F.R.D. 15 (D. Alas. 1953). For removal of physical disability, see Klapprott v. United States, 335 U.S. 601 (1949); Pierre v. Bernuth, Lembcke Co., 20 F.R.D. 116 (S.D.N.Y. 1956). For change of law, see Tsakonites v. 
Although there is some disagreement over the scope of rule 60 (b) (1), ${ }^{15}$ it is generally accepted that a rule granting relief from final judgment may not be found in the first three clauses of rule $60(\mathrm{~b}) .^{16}$ It is also settled that rule $60(\mathrm{~b})(4)$, granting relief if the judgment is void, does not provide an avenue for relief due to a change in law. The courts have clearly rejected the contention that a change of law renders a judgment void. ${ }^{17}$ Therefore, if relief from final judgment is to be available due to a change in law, it must be available under either rule $60(\mathrm{~b})(5)$ or rule $60(\mathrm{~b})(6)$.

\section{A. Rule 60(b)(5): The Current Boundaries}

\section{Rule 60(b)(5) provides for relief from final judgment if}

the judgment has been satisfied, released, or discharged, or a prior judgment upon which it is based has been reversed or otherwise vacated, or it is no longer equitable that the judgment should have prospective application; . . .

The usage of rule $60(b)(5)$ has been based primarily on the third subsection of the rule dealing with the inequity of prospective appli-

Transpacific Carriers Corp., 322 F. Supp. 722 (S.D.N.Y. 1970). But see Delzona Corp. v. Sacks, 265 F.2d 157 (3d Cir. 1959); Morgan v. Southern Farm Bur. Cas. Ins. Co., 42 F.R.D. 25 (W.D. La. 1967).

For a discussion of the time element in seeking relief under rule 60(b), see Comment, Temporal Aspects of the Finality of Judgments: The Significance of Federal Rule 60(b), 17 U. Chi. L. Rev. 664 (1950) [hereinafter cited as Chicago Comment].

15 From dictum in Schildhaus v. Moe, 335 F.2d 529 (2d Cir. 1964), noting that "there is indeed good sense in permitting the trial court to correct its own errors," id. at 531, it could be inferred that a trial court could use rule $60(\mathrm{~b})(1)$ to correct its own errors if the law changes. In Schildhaus, however, such relief was denied. In Tarkington v. United States Lines Co., 222 F.2d 358 (2d Cir. 1955), the Second Circuit granted relief, apparently to correct its error when the law changed eleven days after the final judgment, under rule $60(\mathrm{~b})$. One commentator has implied that this relief ought to be viewed as predicated on rule 60 (b)(1). 11 Wright \& Miller, supra note 12, at 176. However, in Silk v. Sandoval, 435 F.2d 1266 (1st Cir. 1971), cert. denied, 402 U.S. 1012 (1971), Judge Aldrich contended that relief for judicial error of law is available only under rule 59. See also Note, Federal Rule 60(b): Finality of Civil Judgments v. Self-Correction by District Court of Judicial Error of Law, 43 NOTRE DAme L. Rev. 98 (1967). Professor Moore advocates judicial correction of errors of law under rule $60(\mathrm{~b})(1)$, but notes that it is not presently available. 7 Moore, supra note $1, \mathbb{1} 60.22[3]$, at 260-61. But cf. District of C. Fed. Civ. Ass'n v. Volpe, 520 F.2d 451 (D.C. Cir. 1975). See also Note, Pierce v. Cook \& Co.: Change in State Law as a Ground for Relief from a Federal Judgment, 124 U. PA. L. REv. 843, 848-50 (1976).

${ }^{18}$ Rules $60(\mathrm{~b})(2)$ and (3) are inapplicable on their face.

17 Title v. United States, 263 F.2d 28 (9th Cir. 1959); United States v. Failla, 164 F. Supp. 307 (D.N.J. 1958); see Lubben v. Selective Serv., 453 F.2d 645, 649 (1st Cir. 1972) ("In the interest of finality, the concept of void judgments is narrowly construed. . . . Only in the rare instance of a clear usurpation of power will a judgment be rendered void.") See also Phelan v. Bradbury Bldg. Corp., 7 F.R.D. 429 (S.D.N.Y. 1947). 
cation..$^{18}$ In System Federation v. Wright, the Supreme Court held that relief from a continuing injunction was available in the event of a change of law. ${ }^{19}$ The courts have, however, refused to apply the third subsection of clause (5) when the judgment was at law. ${ }^{20}$ Relief from a money judgment has not been available on the ground of prospective inequitability of the judgment. ${ }^{21}$

The courts have given a very narrow construction to the second subsection of rule $60(b)(5)$, which allows relief from judgment on the grounds that "a prior judgment upon which [the final judgment] is based has been reversed or otherwise vacated." Relief has been limited in practice to judgments directly related, by parties and claims, to the prior decision. ${ }^{22}$ For example, relief from an order enforcing a judgment is available if the case establishing liability is subsequently reversed. ${ }^{23}$ A leading commentator has suggested that the second subsection of rule $60(\mathrm{~b})(5)$ cannot be applied to give relief where a precedent relied on by the court is reversed after final judgment, regardless of the extent to which the court relied upon the precedent in reaching its decision. ${ }^{24}$

There is no evidence in the legislative history of rule 60(b)(5) that commands this narrow view of the second subsection. ${ }^{25}$ Fur-

1x For a useful discussion of the third subsection of rule $60(\mathrm{~b})(5)$, and a collection of the major cases interpreting that subsection, see Annot., 14 A.L.R. Fed. 309 (1973).

" 364 U.S. 642, 647 (1960); cf. Harrell v. Harder, 369 F. Supp. 810 (D. Conn. 1974). But cf. McGrath v. Potash, 199 F.2d 166 (D.C. Cir. 1952). See also Block v. Thousandfriend, 170 F.2d 428 (2d Cir. 1948).

${ }^{20}$ Theriault v. Smith, 519 F.2d 809 (1st Cir. 1975); Class v. Norton, 507 F.2d 1058 (2d Cir. 1974); Elgin Nat'l Watch Co. v. Barrett, 213 F.2d 776 (5th Cir. 1954); McGrath v. Potash, 199 F.2d 166 (D.C. Cir. 1952); Harrell v. Harder, 369 F. Supp. 810 (D. Conn. 1974). But cf. Lubben v. Selective Serv., 453 F.2d 645 (1st Cir. 1972); Sunbeam Corp. v. Charles Appliances, 119 F. Supp. 492 (S.D.N.Y. 1953).

${ }^{21}$ Ryan v. United States Lines Co., 303 F.2d 430, 434 (2d Cir. 1962); accord, Daylo v. Administrator of Vet. Aff., 501 F.2d 811 (D.C. Cir. 1974) (by implication).

22 See 7 Moore, supra note $1,\lceil 60.26[3]$, at 325; 11 Wright \& Miller, supra note 12, at 204.

25 Michigan Sur. Co. v. Service Mach. Corp., 277 F.2d 531 (5th Cir. 1960), provides a good example of the narrow construction given the second subsection of rule 60(b)(5). A suit for damages in federal court was based on a state court injunction against attachment involving the same parties and the same claim. After the damages claim in federal court had become final, the injunction was voided in the state court. Relief from the final judgment was given in federal court on the basis of the second subsection of rule $60(\mathrm{~b})(5)$. Id. at 533.

24 7 MoORE, supra note 1, \60.26[3], at 325, citing Title v. United States, 263 F.2d 28 (9th Cir. 1959); Collins v. City of Wichita, 254 F.2d 837 (10th Cir. 1958); Loucke v. United States, 21 F.R.D. 305 (S.D.N.Y. 1957). See also 11 Wright \& Miller, supra note 12, at 205.

${ }^{25}$ Rule 60(b)(5) was proposed in 1946 in Advisory Committee on Rules for Civil Procedure, Report of Proposed Amendments to Rules of Civil Procedure for the District Courts of THE UNITED States (1946) [hereinafter cited as RePorT]. The Report never explicitly mentions rule $60(\mathrm{~b})(5)$; the Report noted that "the federal rules will deal with the practice 
thermore, in Lubben $v$. Selective Service, the First Circuit suggested a broader interpretation of the "based on" language of rule $60(\mathrm{~b})(5)$ in stating that "the prior judgment must be a necessary element of the decision, giving rise, for example, to the cause of action or a successful defense." ${ }^{26}$ Under the broader interpretation suggested by this language, the extent of a court's reliance on a particular precedent in reaching a final judgment would become the crucial factor in determining whether to grant relief from a final judgment when the precedent was subsequently reversed. Mere citation or partial reliance on a particular precedent that was subsequently reversed would be insufficient for the granting of relief under rule $60(\mathrm{~b})(5) .{ }^{27}$ Only if the court could not have reached its decision but for its reliance on a binding and subsequently reversed precedent would relief under the "based on" standard be granted. Although the court in Lubben perhaps did not intend to broaden the

in every sort of case in which relief from final judgments is asked, and prescribe the practice." Id. at 82 . The purpose of this change was to abolish the conflicting relief under the writs and the Federal Rules. See Yale ArTicLe, supra note 2, at 623. The Report also stated that "Rule 60 (b) does not assume to define the substantive law as to the grounds for vacating judgments, but merely prescribes the practice in proceedings to obtain relief." REPORT, supra, at 84 . Beyond this statement, the history of the amendment adding rule $60(\mathrm{~b})(5)$ indicates only that the writs were to be incorporated into the Federal Rules; however, relief has not been limited to the scope of the writs. See Klapprott v. United States, 335 U.S. 601, 614 (1949); Bankers Mort. Co. v. United States, 423 F.2d 73, 77 (5th Cir. 1970).

${ }^{26} 453$ F.2d 645, 650 (1st Cir. 1972).

${ }^{2 \pi}$ Language in Berryhill v. United States, 199 F.2d 217 (6th Cir. 1952), supports this limitation on a broadened interpretation of rule 60(b)(5). In Berryhill the plaintiff sought relief from a judgment denying National Service Life Insurance benefits; since the Supreme Court had ruled in Woodward v. United States, 341 U.S. 112 (1951), that a like-situated party was entitled to the benefits, relief was sought on the basis of, inter alia, rule $60(\mathrm{~b})(5)$. In denying relief under rule $60(\mathrm{~b})(5)$, the court noted:

We are of the opinion that the judgment in this case was not "based" upon a prior judgment which has been reversed or otherwise vacated within the meaning of subsection 5 of Rule $60(\mathrm{~b})$. The ruling of the Court of Appeals for the Eighth Circuit in Woodward v. United States, supra, was not controlling upon the District Judge, sitting in a different circuit, and the record does not show that the District Judge "based" his ruling upon the decision in that case. With the conflicting rulings of the Third and Eighth Circuits before him, each persuasive only, the District Judge ruled in accordance with his own view of the applicable law. Certainly it was not the purpose of the rule to permit a final judgment to be set aside whenever thereafter any case from another jurisdiction involving the same question and decided the same way is later reversed by an Appellate Court.

199 F.2d at 219 (emphasis added).

In Lubben v. Selective Serv., 453 F.2d 645 (1st Cir. 1972), the court noted in dictum that "[i]t is not sufficient that the prior judgment provides only precedent for the decision." Id. at 650 . In Lubben the court "relied heavily" on another district court case which was subsequently reversed, but that was insufficient grounds for relief from the judgment. Id.; cf. Polites v. United States, 364 U.S. 426, 433 (1960). 
interpretation of the "based on" language of rule $60(\mathrm{~b})(5),{ }^{28}$ such a broadened interpretation is not an unnatural reading of the language of the subsection.

The rationale supporting the narrow interpretation of the "based on" language of rule $60(\mathrm{~b})(5)$ has not been made clear by the commentators ${ }^{29}$ or in the cases. ${ }^{30}$ Although the reasons for the narrow interpretation have not been articulated, several can be postulated. The primary reason for the narrow view is likely to be found in the desire to protect the finality of judgments. ${ }^{31}$ However, mere citation to the principle of finality is not a sufficient reason to refuse to grant relief due to a change in law under all circumstances. In some situations finality must and does give way to the equitable considerations that underlie a claim for relief due to a change in law. ${ }^{32}$

Beyond this desire to protect the finality of judgments, another possible explanation for the narrow interpretation of rule $60(\mathrm{~b})(5)$ is the attempt to prevent a flood of litigation when judge-made law changes. Such a flood of litigation would not, however, be likely to result from a use of the interpretation of rule $60(\mathrm{~b})(5)$ suggested by the Lubben court. Under this standard, the court must have relied so heavily on the reversed precedent that it could not have reached its decision without relying on that precedent and the precedent relied upon must be of a binding and not merely persuasive effect. In addition to the express limitations of the Lubben standard, there are three general equitable principles that serve to limit the granting of relief due to a change in law. First, a party must have done all within his power to obtain the proper result before the

22 The Lubben court cited and relied on Professor Moore's narrow interpretation of the "based on" language in reaching its decision that relief could not be granted because the final judgment was not based on the subsequently reversed precedent. And the court, again in dictum, also stated that "a change in applicable law does not provide sufficient basis for relief under Rule 60(b)(5)." Lubben v. Selective Serv., 453 F.2d 645, 650 (1st Cir. 1972).

23 See 7 Moore, supra note 1, If 60.26[3], at 325; 11 WRIGHT \& MillER, supra note 12, at 203. The broad scope of the language of rule 60(b)(5) was noted in Chicago Comment, supra note 14, but no definition was framed. See also 44 Iowa L. REv. 574 (1959) (adopting the narrow definition of rule 60(b)(5) without explanation); Note, Pierce v. Cook \& Co.: Change in State Law as a Ground for Relief from a Federal Judgment, 124 U. PA. L. REv. 843, 848-50 (1976) (adopting Professor Moore's definition of "based on").

${ }_{30}$ See, e.g., Lubben v. Selective Serv., 453 F.2d 645, 650 (1st Cir. 1972); Berryhill v. United States, 199 F.2d 217, 219 (6th Cir. 1952).

${ }^{31}$ See, e.g., Berryhill v. United States, 199 F.2d 217 (6th Cir. 1952).

32 See, e.g., Pierce v. Cook \& Co., 518 F.2d 720 (10th Cir. 1975), cert. denied, 96 S. Ct. 866 (1976); Tsakonites v. Transpacific Carriers Corp., 322 F. Supp. 722 (S.D.N.Y. 1970). 
judgment became final. ${ }^{33}$ Second, the relief must be sought within a reasonable time. ${ }^{34}$ Third, the courts have required that intervening rights not be prejudiced by the granting of relief. ${ }^{35}$ When combined with the Lubben standard, these equitable limitations will prevent a flood of litigation when the law changes.

\section{B. Rule 60(b)(6): The Attempt at Judicial Definition}

Relief from final judgment due to a change in law has been considered primarily under rule 60(b)(6): "any other reason justifying relief." Although the Supreme Court has never addressed the issue of a change of law in relation to rule $60(\mathrm{~b})(6)$, the Court has on three occasions interpreted the rule in a more general context. The lower courts have faced the specific question of relief due to a change in law under the standard as provided in rule 60(b)(6) and interpreted by the Supreme Court. These two sets of precedents will be discussed in turn.

In Klapprott $v$. United States ${ }^{36}$ the petitioner had been deprived of his naturalization in a default judgment procured while the petitioner was ill and wrongfully incarcerated. More than four years later the petitioner sought, and was granted, relief under rule 60 (b)(6). For the majority, Justice Black emphasized the exceptional circumstances of the case and the fact that the petitioner had not had a fair trial. ${ }^{37}$

33 See Ackermann v. United States, 340 U.S. 193 (1950). In Schildhaus v. Moe, 335 F.2d 529 (2d Cir. 1964), the failure to appeal the prior judgment was fatal to relief in circumstances which might have otherwise justified the use of rule $60(\mathrm{~b})(5)$; the courts in Lubben v. Selective Serv., 453 F.2d 645 (1st Cir. 1972), and Berryhill v. United States, 199 F.2d 217 (6th Cir. 1952), also indicated that a failure to appeal was an important consideration.

"See cases cited note 14 supra.

35 In re Cremidas' Estate, 14 F.R.D. 15 (D. Alas. 1953); see Jackson v. Jackson, 276 F.2d 501 (D.C. Cir. 1960). See also 7 Moore, supra note 1, ๆf 60.26[2]-.26[4], at 316-17, 334-35.

Retroactive application of judicial decision was the common practice until 1932. See Ross v. Oregon, 227 U.S. 150 (1913). In that year, in Great N. Ry. v. Sunburst Oil \& Ref. Co., 287 U.S. 358 (1932), the Supreme Court approved the practice of prospective overruling. The prospective-only overruling of judicial decisions has since become a common practice, especially in the field of criminal law. See Linkletter v. Walker, 381 U.S. 618 (1965) (giving prospective-only effect to Mapp v. Ohio, 367 U.S. 643 (1961)). See generally Currier, Time and Change in Judge-Made Law: Prospective Overruling, 51 VA. L. Rev. 201 (1965); Note, Prospective Overruling and Retroactive Application in the Federal Courts, 71 YALE L.J. 907 (1962).

${ }^{36} 335$ U.S. 601 (1949).

37335 U.S. at 614-15. It should also be noted that Klapprott was seeking to overturn a default judgment; the Court emphasized the fact that he had never enjoyed a trial on the merits. Id. at 615 . The courts are perhaps more willing to rely on rule $60(\mathrm{~b})(6)$ when the judgment sought to be overturned was entered by default. See 7 MooRE, supra note 1, I 60.27 [2], at 358 . 
One year later the Court again confronted rule 60(b)(6) in Ackermann $v$. United States. ${ }^{38}$ In Ackermann, the petitioner's citizenship had been revoked in a case that was tried with the case of another German-born citizen (Keilbar); the same result of denaturalization was reached in the two cases. Keilbar appealed, but the petitioner, on the advice of an officer of the Immigration and Naturalization Service, did not. ${ }^{39}$ When Keilbar's case was reversed, the petitioner sought relief under rule 60(b)(6). In denying relief, Justice Minton stated:

Petitioner made a considered choice not to appeal, apparently because he did not feel that an appeal would prove to be worth what he thought was a required sacrifice of his home. This chance was a risk, but calculated and deliberate and such as follows a free choice. Petitioner cannot be relieved of such a choice because hindsight seems to indicate to him that his decision not to appeal was probably wrong, considering the outcome of the Keilbar case. There must be an end to litigation someday, and free, calculated, deliberate choices are not to be relieved from..$^{40}$

Klapprott was distinguished on the basis of its "extraordinary circumstances." These extraordinary circumstances included Klapprott's physical inability to appeal. ${ }^{41}$ For the dissenters, Justice Black argued that petitioner had a right to rely on the advice of the Service; therefore, "fairness" required the application of rule $60(b)(6)$ in this situation. ${ }^{42}$

In Polites $v$. United States, ${ }^{43}$ the petitioner's citizenship had been revoked. He sought relief four years later under rules $60(\mathrm{~b})(5)$ and (6) on the ground that subsequent Supreme Court decisions had changed the law on which petitioner's original case had been decided. Since the petitioner had not appealed the original decision, the Government argued that Ackermann controlled. The crux of the majority's opinion was that even though some cases decided by the Court after petitioner's original judgment reached different conclusions, these cases did not change the law on which petitioner's judg-

\$x 340 U.S. 193 (1950).

31 In order to finance the appeal, petitioner would have had to sell his home; petitioner was advised against this sale. 340 U.S. at 195-96.

t0 340 U.S. at 198.

"Id. at 199.

12 Id. at 202-05.

ง] 364 U.S. 426 (1960). 
ment was based. ${ }^{44}$ Thus the Court reserved the issue whether change of law is grounds for relief under $60(\mathrm{~b}) .^{45}$ For the dissent, Justice Brennan distinguished this case from Ackermann on the basis of the apparent futility of appeal; because of the futility of appeal, the dissent argued that the case must be treated as one in which the petitioner did in fact appeal unsuccessfully. ${ }^{46}$ The dissent also argued that the denaturalization order was based in equity and, therefore, the Court should be able to use rule 60(b)(5) to adjust its ruling in the event of a change of law. ${ }^{47}$

Three important points emerge from a reading of the Supreme Court's interpretation of rule 60(b)(6). First, as the result in Klapprott and the language in Ackermann indicate, ${ }^{48}$ the applicable standard for granting relief under clause (6) is an "extraordinary circumstances" standard. Second, the language in Klapprott suggests that, in applying this standard, a court must operate in an ad hoc manner, balancing the need to protect finality against the court's perceived need to do justice in the individual case. ${ }^{49}$ Third, Ackermann establishes that when a litigant has made a considered choice not to appeal before the judgment became final, relief from that judgment should not be given even if there are extraordinary circumstances. Whether or not relief should be granted if the litigant failed to appeal because of the apparent futility of such action is a question left open by the cases. The majority in Polites expressly left this question open, while the dissent argued vigorously that failure to appeal because of futility should not bar relief under clause (6) of rule $60(\mathrm{~b}) .^{50}$ Perhaps the broadest rule that can be drawn from these cases with any certainty is that in exceptional circumstances rule 60(b)(6) gives the courts the power to grant relief from a final judgment as long as the party has not freely and deliberately failed to appeal. ${ }^{51}$ In Polites the Court reserved the issue of

"In holding that the reversal of the prior judgments did not affect the petitioner's case, the Court was applying criteria similar to the "based on" criteria suggested by this comment for use under rule $60(\mathrm{~b})(5)$. The majority did not reach the change of law issue because the result in petitioner's case would have been the same, the change in law notwithstanding.

364 U.S. at 433.

16364 U.S. at 438.

"Id. at 438-40.

is 340 U.S. at 199.

19335 U.S. at $614-15$.

so See text at note 44 supra.

${ }^{51}$ In other cases the courts have established additional rules of a more particular nature for the application of rule 60 (b)(6):

(a) The motion must be made within a "reasonable time." In re Cremidas' Estate, 14 F.R.D. 15 (D. Alas. 1952); see note 14 supra. 
whether a change of law constitutes such exceptional circumstances. ${ }^{52}$ The lower courts have failed to resolve this issue in a systematic or consistent manner.

The issue as to whether a change in law can be the basis for relief under rule 60(b)(6) has been faced on seven occasions by the lower courts. Of these seven cases, only three-Collins v. City of Wichita, ${ }^{53}$ Tsakonites $v$. Transpacific Carriers Corp.,${ }^{54}$ and Pierce $v$. Cook \& Co. ${ }^{55}$-shed any light on the issues left unanswered by the Supreme Court and, unfortunately, these cases are in conflict. The remaining cases, in which failure to appeal was fatal to relief, merely echo the concepts first developed by the Supreme Court. ${ }^{56}$

(b) "Clause (6) is a residual clause to be invoked only on the basis of some reason other than those specified in the preceding clauses (1)-(5)." FDIC v. Alker, 30 F.R.D. 527, 532 (E.D. Pa. 1962), aff'd, 316 F.2d 236 (3d Cir. 1963).

(c) A lower court cannot relieve the final judgment of a higher court; e.g., a district court cannot grant a rule $60(\mathrm{~b})(6)$ motion if the judgment has been appealed. See International Ry. v. Davidson, 65 F. Supp. 58 (W.D.N.Y. 1945).

(d) Relief under rule 60(b)(6) is discretionary. Radack v. Norwegian Amer. Line Agency, 318 F.2d 538 (2d Cir. 1963); Delzona Corp. v. Sacks, 265 F.2d 157 (3d Cir. 1959); United States v. Karahalias, 205 F.2d 331 (2d Cir. 1953).

(e) Intervening rights cannot be prejudiced. In re Cremidas' Estate, 14 F.R.D. 15 (D. Alas. 1953).

(f) Rule 60(b)(6) is not a substitute for appeal. Ackermann v. United States, 340 U.S. 193 (1950).

52 See text at note 45 supra.

53254 F.2d 837 (10th Cir. 1958).

34322 F. Supp. 722 (S.D.N.Y. 1970).

ss 518 F.2d 720 (10th Cir. 1975), cert. denied, 96 S. Ct. 866 (1976).

ss Lubben v. Selective Serv., 453 F.2d 645 (1st Cir. 1972); Title v. United States, 263 F.2d 28 (9th Cir. 1959); Berryhill v. United States, 199 F.2d 217 (6th Cir. 1952); Loucke v. United States, 21 F.R.D. 305 (S.D.N.Y. 1957).

In three other cases relief was granted due to a change of law. However, these cases are to be distinguished from the other cases applying rule 60(b)(6) which this comment discusses.

In Weilbacher v. United States, 99 F. Supp. 109 (S.D.N.Y. 1951), the plaintiff's action for libel in admiralty against a general agent of the United States had been dismissed on the basis of McAllister v. Cosmopolitan Shipping Co., 337 U.S. 783 (1949). Subsequently, Congress passed the Enabling Act, 46 U.S.C. $\$ 745$ (1970), retroactively authorizing suits against government agents. The court allowed Weilbacher relief from the original judgment under rule $60(\mathrm{~b})(6) .99 \mathrm{~F}$. Supp. at 111 . This case is outside the scope of this comment since the change of law was statutory, not judicial, as Congress had created a new cause of action. Relief in this situation was a function of judicial deference to the legislature; this comment is concerned solely with relief due to a judicial change in law.

In Tarkington v. United States Lines Co., 222 F.2d 358 (2d Cir. 1955), plaintiff's action based on unseaworthiness ended in a directed verdict for the defendant. Eleven days after the judgment became final the Supreme Court, in an unrelated case, reversed the case relied upon by the trial court. Plaintiff, who had not appealed, moved for a new trial. Recognizing that the motion for a new trial was properly denied as untimely, the Second Circuit held that relief should be granted under rule 60 (b), without specifying which clause applied. Id. at 35960. One commentator implies that relief in Tarkington was granted under rule 60(b)(1). See 7 Moore, supra note 1, ๆ 60.22[3], at 260-64; note 15 supra; cf. District of Columbia Fed. 
Collins concerned the validity of the notice requirements in a state condemnation statute. Plaintiff challenged the validity of the statute and appealed an adverse decision. The court of appeals affirmed, and certiorari was denied. More than a year later, in another case involving different parties, the Supreme Court held that the statute was invalid. ${ }^{57}$ In denying relief under rule $60(\mathrm{~b})(6)$, the court noted:

[I]n the present case the appellants did appeal. . . . The only difference in appellant's situation and that of Ackermann is that their appeal was perfected and the judgment became final after the appeal. In attempting to obtain relief from a final judgment, there is no reason why an unsuccessful appellant should be in a better position than one who did not appeal

\section{Litigation must end some time. ${ }^{58}$}

In Tsakonites a seaman moved to vacate the prior dismissal of his action which had been brought under the Jones Act and the general maritime law. In the original suit, the lower courts ruled that plaintiff's contacts with the United States (plaintiff was a Greek national) were insufficient to justify application of the Jones Act or the general maritime law; the Supreme Court denied certiorari. ${ }^{59}$ In a similar case five years later the Supreme Court held that the continuing contacts of the shipping company would justify application of the Jones Act in favor of a similarly situated party.$^{60}$ The Court noted the conflict in the circuits involving Tsakonites's origi-

Civ. Ass'n v. Volpe, 520 F.2d 451 (1975). One possible interpretation of Tarkington is that, since the change in law occurred so soon after the judgment became final, the court, for equitable reasons, felt compelled to grant relief under rule $60(\mathrm{~b})(6)$, plaintiff's failure to appeal notwithstanding. If so, Tarkington is clearly out of line with Ackermann.

In Amsden v. United States, 175 F. Supp. 147 (Ct. Cl. 1959), the plaintiff had participated in a prior suit which was settled. Another litigant (Tanner) contested the application of the Economy Act which had controlled in all such cases; before Tanner's case was concluded, plaintiff sought relief under rule 54(b) of the Rules of the Court of Claims (which is substantially similar in language to FED. R. CIv. P. 60(b)). The Court of Claims granted relief on the basis of "our sense of justice." Id. at 148. The dissent based its conclusion on cases decided under rule $60(\mathrm{~b})$, arguing that relief should not be available since the plaintiff had not appealed and relief is not available in the event of a change of law. The Court of Claims, in allowing relief against the government, appears to have given itself more leeway than its rules might otherwise allow. Plaintiff's failure to appeal would have been fatal in the district courts. See Ackermann v. United States, 340 U.S. 193 (1950).

57 Walker v. Hutchinson City, 352 U.S. 112 (1956).

${ }^{38} 254$ F.2d at 839 .

s9 386 U.S. 1007 (1967).

${ }^{\text {f0 }}$ Hellenic Lines v. Rhoditis, 398 U.S. 306 (1970). 
nal case. ${ }^{61}$ Tsakonites sought relief under rules $60(\mathrm{~b})(5)$ and (6); in light of the change of law, the court granted relief without articulating the clause on which it relied. ${ }^{62}$

The original suit in Pierce coneerned an automobile accident in which Pierce, Davis, and Ellenwood, riding in the same car, were injured by Edwards, an independent contractor working for the defendant-shipper. Pierce and the others filed separate suits in state court, all of which were removed to the federal courts. Davis was able to dismiss his suit and refile it in state court with a guardianship provision that destroyed diversity. In Pierce's case, the federal district court granted Cook summary judgment on the basis of an Oklahoma case ${ }^{63}$ which relieved a shipper of liability for the torts of an independent contractor. Pierce's appeal was unsuccessful since, under the Erie rule, ${ }^{64}$ Oklahoma law controlled. More than three years after Pierce's original judgment became final, Davis's case reached the Oklahoma Supreme Court. The court specifically overruled the Oklahoma precedent previously relied on ${ }^{65}$ and remanded the case. ${ }^{66}$ Pierce and Ellenwood then filed for relief under rule 60 (b); the court granted relief under rule $60(\mathrm{~b})(6)$.

For the majority of the court, ${ }^{67}$ Judge Breitenstein distinguished Collins on the grounds that the decisional change of law in Collins came in an unrelated case. Emphasis was placed on Gondeck v. Pan American World Airways, ${ }^{68}$ a common accident case which, however, did not involve rule 60(b). In Gondeck the Supreme Court granted a petition for rehearing of a denial of certiorari and reversed judgment in order to reach consistent results in the common cases. ${ }^{69}$ Judge Breitenstein also stressed that the Erie rule had been violated in that " $[t]$ he federal courts in which plaintiffs were forced to litigate have given them substantially different treatment than that received in state court by another injured in the same

61 Id. at 307.

${ }^{82}$ The court relied on Tarkington v. United States Lines Co., 222 F.2d 358 (2d Cir. 1955), as precedential support for relief in this situation. Reliance on Tarkington, however, was inappropriate; see note 56 supra.

6s Marion Mach., Foundry \& Supply Co. v. Duncan, 187 Okla. 160, 101 P.2d 813 (1940).

" Erie R.R. v. Tompkins, 304 U.S. 64 (1938). For a discussion of the application of the Erie doctrine to the situation presented in Pierce, see Note, Pierce v. Cook \& Co.: Change in State Law as a Ground for Relief from a Federal Judgment, 124 U. PA. L. Rev. 843 (1976).

* Hudgens v. Cook Industries, 521 P.2d 813 (Okla. 1974).

ss Id. The case was then settled favorably for the plaintiff.

67 The Tenth Circuit heard the case en banc, eight judges sitting.

* 382 U.S. 25 (1965).

69 Id. at 27 . 
accident."70 In his concurring opinion, Judge Barrett emphasized that this case succinctly presented the difficulty of applying changing state law in the federal forum. Judge Barrett argued that relief from a final judgment should only be available to the party that did not invoke federal jurisdiction. ${ }^{71}$

All of these cases are in agreement with the Ackermann principle that appeal is a necessary condition for relief under rule $60(\mathrm{~b})(6)$. However, the cases conflict as to whether, after appeal, a judicial change of law is a sufficient condition for relief. The two cases which meet the necessary condition of appeal, Tsakonites and Collins, are in conflict. A similar conflict exists between Collins and Pierce, although it could be argued that the need to conform to the Erie doctrine (and not the change of law) was the condition sufficient for relief in Pierce. ${ }^{72}$ Thus, Pierce does not answer this question since there were other factors in that case which could have been sufficient to create the exceptional circumstances justifying relief. Taken together, the seven cases considering a change of law under rule $60(\mathrm{~b})(6)$ do not present a consistent picture.

III

\section{A. Comparison of the Present System with the Conflicting Goals of Finality and Equity}

As a practical matter, relief from final judgments in the event of a change of law is available only under rule $60(\mathrm{~b})(6)$; relief under rule $60(\mathrm{~b})(5)$ is limited to orders with prospective application, and the "based on" language of rule $60(\mathrm{~b})(5)$ has been applied very narrowly. The efficacy of granting relief under rule 60(b)(6) must be considered in light of the goals of any system granting relief from final judgments. The lack of clarity as to whether a judicial change of law constitutes the extraordinary circumstance required by rule

${ }^{70} 518$ F.2d at 723. The basis for relief under rule 60(b)(6) in Pierce can be seen as the court's desire to make the Erie doctrine work; this promotion of the Erie doctrine would constitute the exceptional circumstances justifying relief. The major theoretical underpinning of the Erie doctrine is that litigation will reach the same results whether in the state or federal courts. Guaranty Trust Co. v. York, 326 U.S. 99 (1945). To achieve the results mandated in Guaranty Trust, the court in Pierce was compelled to grant relief. This desire to apply the Erie doctrine, strongly reflected in the majority's opinion, may have been a sufficient condition to grant relief under rule $60(\mathrm{~b})(6)$. The court does not clearly indicate whether the Erie doctrine, or the change of law, or the equities of the situation, or all three, was the decisive factor in granting relief under rule $60(\mathrm{~b})(6)$.

7518 F.2d at 724-25. Judges Lewis and Seth argued in dissent that the court was overruling the Collins case. Id. at 726.

i2 See text and note at note 70 supra. 
60(b)(6) has led to inconsistent results through a rule which is both uncertain and difficult to apply. Rather than promote finality and equitable results, the present method of granting relief in the event of a change of law has drawn these two ideals into conflict.

The primary source of confusion in granting relief under rule $60(\mathrm{~b})(6)$ is that the rule provides no greater guidance than "any other reason justifying relief." From an equitable standpoint, it could be argued that an unrefined rule for relief allows the courts leeway to cope with new circumstances. However, in this situation the lack of guidelines for relief has made the granting of relief in the event of a change of law inequitable in relation to the similar cases in which relief has been denied. Similarly, the goals of finality have not been furthered by application of rule $60(\mathrm{~b})(6)$. The case law is clearly inconsistent. Finality of judgments is designed in part to bring an end to litigation, but the inconsistent results under rule $60(b)(6)$ could encourage any litigant to seek relief when the law changes. Finality of judgments is furthered by clear rules of law, but the cases conflict in treating a change of law as sufficient ground for relief from a final judgment. Finality also has its equitable overtones as it protects judgments won, but this protection is also lessened by the lack of certainty as to when the court will grant relief from a final judgment.

\section{B. A Proposed Solution}

To promote the ideals of finality and equitable results, it is submitted that relief in the event of a judicial change of law should be governed by rule $60(\mathrm{~b})(5)$. The present distinction, granting relief in cases in equity under rule $60(\mathrm{~b})(5)$ and cases at law under rule 60 (b)(6), would be abolished. ${ }^{73}$ Rule 60 (b)(5) would not be limited by the narrow interpretation which the courts have previously given it but rather would implement the plain meaning of its words. Application of rule $60(\mathrm{~b})(5)$ in the event of a change of law would lead to consistent results through a rule which would be easier to apply than the "extraordinary circumstances" requirement of rule $60(b)(6)$.

The language of rule $60(\mathrm{~b})(5)$ is broad enough to encompass relief from judgments in the event of a judicial change of law: the rule provides for relief when

${ }^{73}$ Rule 2 of the Federal Rules merges the actions which formerly had been at law or in equity; limiting relief in the event of a judicial change of law to rule $60(\mathrm{~b})(5)$ would cause a similar merger and is therefore not inconsistent with the framework of the Federal Rules. 
a prior judgment upon which it is based has been reversed or otherwise vacated ....

The plain meaning of rule $60(\mathrm{~b})(5)$ suggests that it provides the basis for relief in the event of a judicial change of law; this meaning has not been adopted. Adoption of the plain meaning of rule $60(\mathrm{~b})(5)$ as the basis for relief in the event of a change of law is preferable to the present usage of rule $60(\mathrm{~b})(6)$. Once adopted, this clause would serve as the sole avenue for relief due to a change in law because of the mutual exclusivity requirement.

Relief under rule 60(b)(5) would be available in those circumstances which the language indicates. In the first place, the decision from which relief is sought must have been based on a prior judgment. The term "judgment" has a plain meaning, including decisions of courts and, perhaps, administrative agencies; "j4 "judgment" would include decisions which formerly would have been either at law or in equity. The term "based on" would follow the definition of earlier cases such as Lubben $v$. Selective Service which conclude that a judgment has been based on another if the precedent was binding, rather than merely persuasive, and if, but for reliance on the prior judgment, a different result would have obtained.75

Furthermore, the prior judgment must have been "reversed or otherwise vacated." It is submitted that this language encompasses the overruling of the case at a later time. It could be argued that the language of rule $60(\mathrm{~b})(5)$ encompasses only the direct reversal (presumably on appeal) of the prior judgment, but this interpretation ignores the "otherwise vacated" portion of the subsection. The cases have not directly interpreted this language ${ }^{76}$ but the plain meaning of the clause is sufficiently broad to encompass the subsequent overruling of a decision.

The method of application of rule $60(b)(5)$ in the event of a change of law would vary greatly from the method of application of rule 60(b)(6). Rather than determine on an ad hoc basis if the circumstances are exceptional enough to merit relief, relief under rule

is In Class v. Norton, 507 F.2d 1058 (2d Cir. 1974), relief from an injunctive order was granted pursuant to the change of an administrative ruling. See also Block v. Thousandfriend, 170 F.2d 428 (2d Cir. 1948), granting relief from a judicial order after an administrative agency reversed its prior decision.

is See text at notes 26-31 supra.

${ }^{76}$ In equity cases involving a change of law, the overruling of the basis for the decision has been sufficient. System Fed'n v. Wright, 364 U.S. 642 (1950); McGrath v. Potash, 199 F.2d 166 (D.C. Cir. 1952). But see Lubben v. Selective Serv., 453 F.2d 645 (1st Cir. 1972). The dissent in Polites v. United States, 364 U.S. 426 (1960), implies that the overruling of a prior judgment is within the meaning of rule $60(\mathrm{~b})(5)$. 
$60(b)(5)$ would simply require a step-by-step application of the language of the rule. The necessary and sufficient conditions for relief would be the reversal of a prior judgment on which the decision was based, coupled with the absence of other equitable reasons (such as failure to take all possible steps before judgment, failure to seek relief within a reasonable time, or the prejudice of intervening rights) ${ }^{77}$ which would mandate a denial of relief. If the necessary and sufficient conditions for relief were met, relief would be granted.

-Rule $60(\mathrm{~b})(5)$ basically provides a mechanical rule for determining if relief is available in the event of a change of law. The automatic quality of rule $60(\mathrm{~b})(5)$ is tempered by judicial discretion in determining if the equitable requirements of relief (e.g., timeliness of request have been satisfied. The effect of applying rule 60 (b)(5) is to increase the certainty, consistency, and ease of granting relief in the event of a change of law. The most difficult aspect of the application of rule $60(\mathrm{~b})(5)$ would be to determine whether the reversed judgment has been "based on" the later case, but the proposed definition of this term should be sufficiently clear to provide guidance to the court. For the litigant, the certainty of a final judgment would be a function of whether the case was "based on" a questionable prior judgment. If the litigant's judgment rested on a solid legal foundation built on many principles, the finality of that judgment would be certain. If the judgment was, however, balanced precariously on a single case, the finality of that judgment would be based on the case on which it rested. Besides providing a consistent. basis for relief from judgments, whether at law or in equity, the application of rule $60(\mathrm{~b})(5)$ would lead to more consistent results. Under rule $60(\mathrm{~b})(6)$ inconsistent results were foreshadowed by the vagueness of the tests for relief; rule $60(\mathrm{~b})(5)$ provides the concrete guidelines which should lead to consistent results.

The ultimate test of applying rule $60(\mathrm{~b})(5)$ as the basis for relief in the event of a change of law is whether such relief can be granted without sacrificing, to any great extent, either the finality of judgments or equity of results. In contrast to rule 60(b)(6), which has fostered inconsistent results which are contrary to both equity and finality, the narrow criteria of rule $60(\mathrm{~b})(5)$ should lead towards the satisfaction of both of these ideals. Although, by definition, any relief from judgments is contrary to the absolute principle of finality, relief is least deleterious to finality if it is limited to carefully defined circumstances. Since relief is to be granted under rule $60(\mathrm{~b})$,

${ }^{77}$ See text and notes at notes 33-35 supra. 
finality is strengthened most by a rule which clearly lists the criteria for such relief. Furthermore, the cases indicate that relief can be obtained in the event of a change of law; if such relief is to be granted, finality demands strict parameters. In contrast to the vague guideline of "exceptional circumstances" provided by rule $60(\mathrm{~b})(6)$, the literal language of rule $60(\mathrm{~b})(5)$ clearly provides the grounds for relief. Consistency and certainty are the bulwarks of finality - the specificity of rule $60(\mathrm{~b})(5)$ bolsters both of these goals.

Relief under rule 60(b)(5), however, does not further the finality of judgments at the expense of equitable goals. The basic equitable principle behind relief in the event of a change of law-like cases producing like results-is furthered. When a decision satisfies the "based on" interpretation suggested by this comment, relief is warranted as a matter of equity ${ }^{78}$ But the certainty of when such relief is to be available is also an equitable concern which rule $60(b)(5)$, in contrast to rule 60(b)(6), fosters. Finally, if a case presents exceptional circumstances, relief could be granted under rule $60(b)(6)$ unless the mutual exclusivity rule would bar its application. ${ }^{79}$

\section{ConCLUSION}

Rule 60(b)(5) provides the grounds for relief needed to achieve equitable results without totally undermining the rule of finality. Under rule $60(\mathrm{~b})(6)$, there is confusion as to whether a change of law constitutes the extraordinary circumstances justifying relief; the adoption of the guidelines of the plain language of rule 60(b)(5) would eliminate that confusion. When combined with the general equitable parameters of relief, the suggested guidelines for determining when to give relief due to a change in law would provide consistency, certainty, and an ease of application. The balance between achieving equitable results when the law changes, and the need for finality, could be maintained. If there is to be relief due to a judicial change of law, whether the decision was at law or in equity, relief should be governed by rule $60(\mathrm{~b})(5)$.

Richard M. Lipton

${ }^{75}$ See note 35 supra.

79 Weilbacher v. United States, 99 F. Supp. 109 (S.D.N.Y. 1951), involved a legislative change of the law. In this circumstance relief would not be available under rule $60(\mathrm{~b})(5)$ since no prior judgment has been reversed. This case represents the exception for which relief would be available under rule $60(\mathrm{~b})(6)$. The mutual exclusivity rule would not bar the application of rule $60(b)(6)$ in this situation since there has not been a judicial change of law. 